\title{
Emission analysis of biogas premixed charge diesel dual fuelled engine
}

\author{
Hitesh N Prajapati ${ }^{1 *}$, Tushar M Patel ${ }^{2}$ and Gaurav P Rathod ${ }^{3}$ \\ ${ }^{I}$ M.E Scholar, Thermal Engineering, LDRP-ITR, Gandhinagar. \\ ${ }^{2}$ Associate Professor, LDRP-ITR, Gandhinagar \\ ${ }^{3}$ Assistant Professor, LDRP-ITR, Gandhinagar
}

\begin{abstract}
Increased environmental awareness of resources is driving the industries to develop alternative fuel like Biogas, vegetable oil, CNG, LPG, Producer gas etc.In order to provide suitable substitute of diesel to compression ignition engine. In this investigation, a single cylinder 4-stroke research diesel engine to use biogas in dual fuel mode. The biogas is premixed with air and supplied through inlet manifold.emmision characteristics were studied and compared for neat fuel and dual fuel mode. The experimental result shows the emission of $\mathrm{NOx}$ and $\mathrm{CO}_{2}$ dual fuel has lower than the neat fuel operation. The NOx is reduced $27 \%$ to $57 \%$ and $\mathrm{CO} 2$ emission is reduced from $4 \%$ to $18 \%$ from lower load to higher load condition. The emission of $\mathrm{HC}, \mathrm{CO}$ and $\mathrm{O} 2$, dual fuel has higher than the neat fuel operation. The $\mathrm{HC}$ emission is $200 \mathrm{ppm}$ at lower load and this reduced to $63 \mathrm{ppm}$ at higher lad than the neat fuel. CO emission at $0.17 \%$ at low load and this reduced to $0.05 \%$ which almost same value as neat fuel. And O2 emission is $0.19 \%$ higher than the neat fuel operation and this difference is increased with load and the $\mathrm{O} 2$ emission is increased to $1.08 \%$.
\end{abstract}

Keywords: - Biogas, Diesel, Dual fuel, Emission

\section{INTRODUCTION}

Current energy situation throughout the world and the fact that main resources of energy, such as crude oil, natural gas, coal and nuclear fuel are not renewable give importance to other sources of energy, like hydro energy, solar energy, energy of wind and biogas. Mentioned sources of energy are all renewable, but biogas is particularly significant because of possibility of use in internal combustion engines, which are the main power source for transport vehicles and also commonly used for powering of generators of electrical energy. This possibility of use is justified by biogas properties, which make it convenient for IC engines.

India is largest cattle breeding country; there is abundance of raw material for producing biogas. Also municipal wastes \& kitchen wastes can be used for this purpose. The use of methane $\left(\mathrm{CH}_{4}\right)$ separated from biogas as a fuel will substantially reduce harmful engine emission and will help to keep the environment clean. Biogas consists of approximately 50-70 \% methane. It is economical and slurry can be used as organic manure. In 1981 an effort has been made to use biogas in a converted compression ignition (CI) engine to spark ignition (SI) engine by D. J. Hickson. He experienced 35\% less power compared to diesel and $40 \%$ less compared to gasoline fuel. In that year another research was done by S. Neyeloff and W. W. Cunkel [1]. They used a CFR engine and ran it with simulated biogas in different compression ratios. They reached to compression ratio of 15:1 for optimal solution. The lower heating value, corrosive composition and difficulties in transportation of the fuel were main challenges for biogas.

Biogas is produced by extracting chemical energy from organic materials in a sealed container called a digester. The generation of biogas is the concept of anaerobic digestion, also called biological gasification. It is a naturally occurring, microbial process that converts organic matter to methane and carbon dioxide. The chemical reaction takes place in the presence of methanogenic bacteria with water an essential medium. The anaerobic digestion process, as the name states, is one that functions without molecular oxygen. Ideally, in a biogas plant there should be no oxygen within the digester. Oxygen removal from the digester is important for two main reasons. First, the presence of oxygen leads to the creation of water, not methane. Second, oxygen is a contaminant in biogas and also a potential safety hazard. Due to presence of oxygen, calorific value of biogas becomes low. 


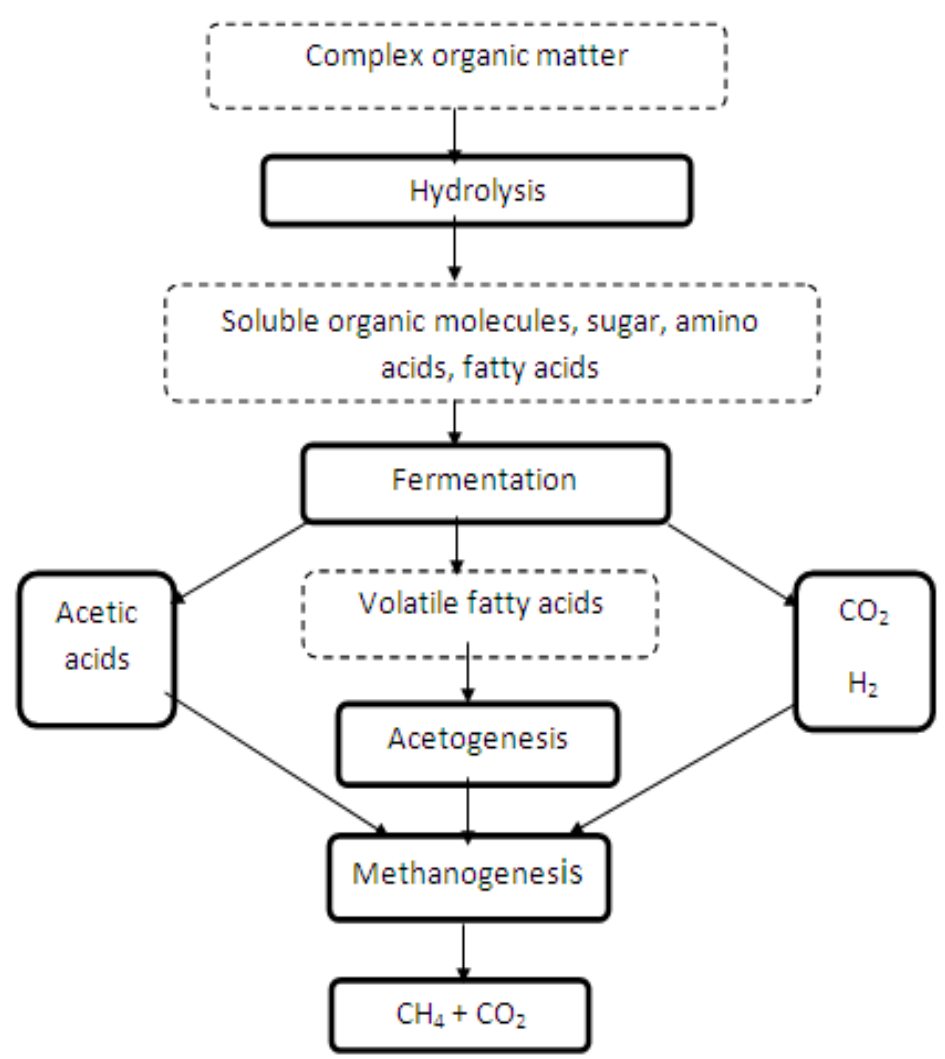

Fig.1 Anaerobic digestion

The general composition of biogas is methane, carbon dioxide, hydrogen, nitrogen, water vapour and traces of hydrogen sulphide as shown in table-1 and 2[3]:

Table.1 Composition and constituent of biogas

\begin{tabular}{|c|c|c|}
\hline Constituent & By volume & By mass \\
\hline $\mathrm{CO}_{2}$ & $19 \%$ & $37.28 \%$ \\
\hline $\mathrm{N}_{2}$ & $6.5 \%$ & $8.14 \%$ \\
\hline $\mathrm{O}_{2}$ & $1.5 \%$ & $2.15 \%$ \\
\hline $\mathrm{CH}_{4}$ & $73 \%$ & $52.34 \%$ \\
\hline $\mathrm{H}_{2} \mathrm{~S}$ & $20 \mathrm{ppm}$ & - \\
\hline Density & $0.9145 \mathrm{~kg} / \mathrm{m}^{3}(273 \mathrm{~K} .1 \mathrm{~atm})$ & - \\
\hline$(\mathrm{A} / \mathrm{F}) \mathrm{s}, \mathrm{CH} 4$ & 17.23 & - \\
\hline
\end{tabular}

Biogas generally has a high self-ignition temperature hence; it cannot be directly used in a CI engine. So it is useful in dual fuel engines. The dual fuel engine is a modified diesel engine in which usually a gaseous fuel called the primary fuel is inducted with air into the engine cylinder. This fuel and air mixture does not auto ignite due to high octane number. A small amount of diesel, usually called pilot fuel is injected for promoting combustion. The primary fuel in dual fuelling system is homogeneously mixed with air that leads to very low level of smoke. Dual fuel engine can use a wide variety of primary and pilot fuels. The pilot fuels are generally of high Cetane fuel. Biogas can also be used in dual fuel mode with vegetable oils as pilot fuels in diesel engines [7]. 


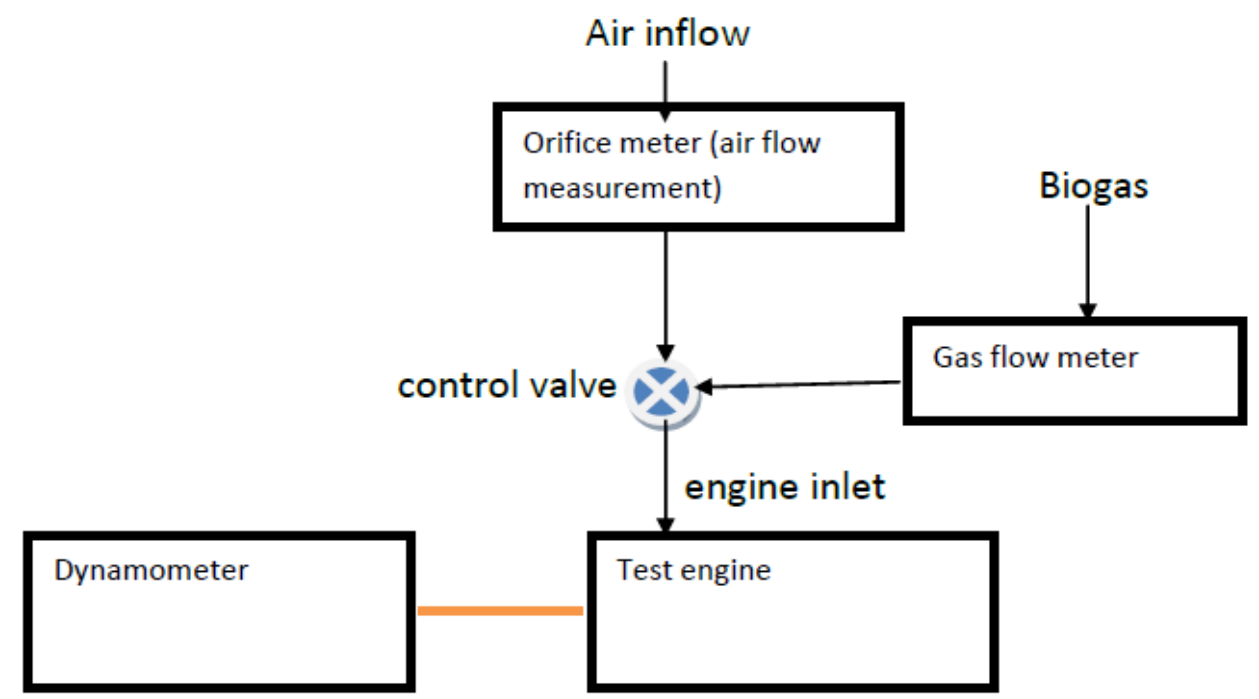

Fig.2 Dual fuel operation

Introduction of biogas normally leads to deterioration in performance and emission characteristics. The performance of engine depends on the amount of biogas and the pilot fuel used. Measures like addition of hydrogen, LPG, removal of $\mathrm{CO}_{2}$ etc. have shown significant improvements in the performance of biogas dual fuel engines. The ignition delay of the pilot fuel generally increases with the introduction of biogas and this will lead to advance the injection timing. Injectors opening pressure and rate of injection also are found to play important role in the case of biogas fuelled engine, where vegetables oil is used as a pilot fuel. The $\mathrm{CO}_{2}$ percentage in biogas acts as diluents to slow down the combustion process in Homogenous charged compression ignition (HCCI) engines. However, it also affects ignition. Thus a fuel with low self-ignition temperature could be used along with biogas to help its ignition. This kind of engine has shown a superior performance as compared to a dual fuel mode of operation [8].

\section{EXPERIMENTAL SETUP AND METHODOLOGY}

The fuels selected for evaluation and analyze of engine performance were methane enriched biogas and pure diesel oil. Some important fuel properties of these selected gaseous fuels are given in Table-2. A substantial change in methane and carbon dioxide contents in the produced biogas does not take place unless there is drastic change in environmental operating parameters and/or change in quality of input feed material. However, there is always a little variation in composition of produced biogas with time according to the activities of anaerobic bacteria. Methane enrichment of biogas originally containing $65 \%$ methane and $32 \%$ carbon dioxide with $3 \%$ other gases was carried out using a water scrubbing system. $95 \%$ purity methane was obtained at the outlet when the system was operating at $1.0 \mathrm{MPa}$ operating column pressure and $2.5 \mathrm{~m}^{3} / \mathrm{h}$ biogas flow rate. Methane enriched biogas was stored in 5001 mild steel tank at pressures lower than 1.0 MPa. Further, it was supplied to the engine by using a pressure reducing valve.

Table.2 Properties of biogas and diesel

\begin{tabular}{|c|c|c|}
\hline Property & Biogas & Diesel \\
\hline Relative density & 1.11 & 0.837 \\
\hline Flame speed (cm/s) & 25 & - \\
\hline Stoichiometric A/F (Kg of air/kg of fuel) & 17.23 & 15.0 \\
\hline Auto ignition Temperature (C) & $650-750$ & $250-300$ \\
\hline LHV & $26.17 \mathrm{MJ} / \mathrm{kg}$ & $42 \mathrm{MJ} / \mathrm{kg}$ \\
\hline
\end{tabular}



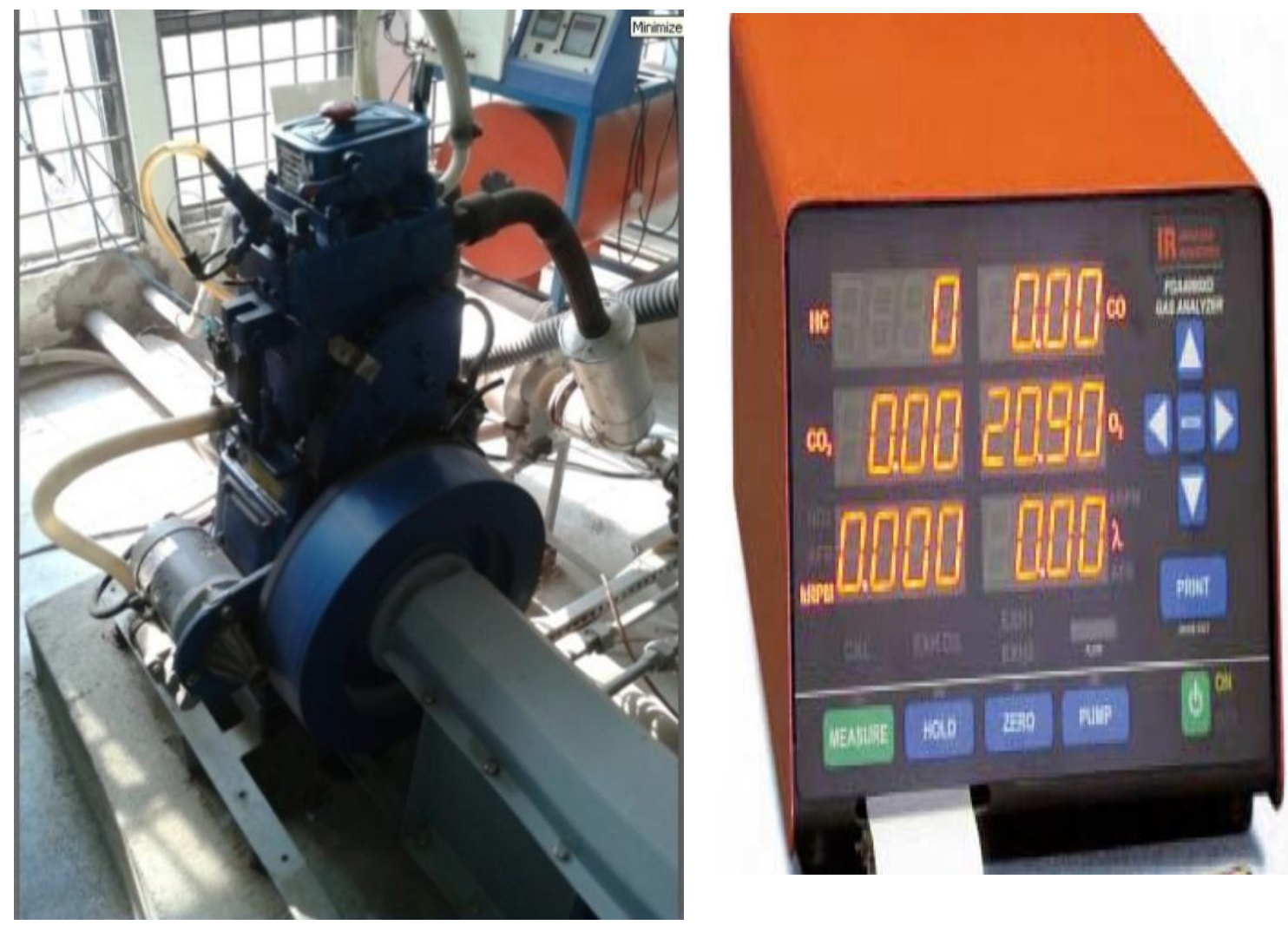

Fig.3 Single cylinder, four stroke, multi-fuel, research engine connected to eddy type dynamometer and DC five gas analyzer.

The setup consists of single cylinder, four stroke, multi-fuel, research engine connected to eddy type dynamometer for loading and DCfive gas analyzer connected measures five emission gases, including Hydrocarbons (HC), Carbon Monoxide (CO), Carbon Dioxide (CO2), Oxygen (O2) and Oxides of Nitrogen (NOX). The operation mode of the engine can be changed from diesel to Petrol of from Petrol to Diesel with some necessary changes. The specification of the research engine is given in table-3. The operation mode of the engine can be changed from diesel to petrol of from petrol to diesel with some necessary changes. In both modes the compression ration can be varied without stopping the engine and without altering the combustion chamber geometry by specially designed tilting cylinder block arrangement.

The injection point and spark point can be changed for research tests. Setup is provided with necessary instruments for combustion pressure, Diesel line pressure and crank-angle measurements. These signals are interfaced with computer for pressure crank-angle diagrams. Instruments are provided to interface airflow, fuel flow, temperatures and load measurements. The set up has stand-alone panel box consisting of air box, two fuel flow measurements, process indicator and hardware interface. Rota meters are provided for cooling water and calorimeter water flow measurement. A battery, starter and battery charger is provided for engine electric start arrangement.

The setup enables study of VCR engine performance for brake power, indicated power, frictional power, BMEP, IMEP, brake thermal efficiency, indicated thermal efficiency, Mechanical efficiency, volumetric efficiency, specific fuel consumption, A/F ratio, heat balance and combustion analysis. Lab view based Engine Performance Analysis software package "Engine soft" is provided for on line performance evaluation.

Table.3 Engine specification

\begin{tabular}{|c|c|}
\hline Model & TV1 \\
\hline Make & Kirlosker Oil Engines \\
\hline Type & Four stroke, Water cooled, Diesel \\
\hline No. of cylinder & One \\
\hline Bore & $87.5 \mathrm{~mm}$ \\
\hline Stroke & $110 \mathrm{~mm}$ \\
\hline Combustion principle & Compression ignition \\
\hline Cubic capacity & 0.661 liters \\
\hline
\end{tabular}


Emission analysis of biogas premixed charge diesel dual fuelled engine

\begin{tabular}{|c|c|}
\hline Compression ratio 3 port & $17.5: 1$ \\
\hline Peak pressure & $77.5 \mathrm{~kg} / \mathrm{cm}^{2}$ \\
\hline Max. Speed & $2000 \mathrm{rpm}$ \\
\hline Min. idle speed & $750 \mathrm{rpm}$ \\
\hline Min. operating speed & $1200 \mathrm{rpm}$ \\
\hline Fuel timing for std. engine & 0 to $25 \mathrm{BTDC}$ \\
\hline Connecting rod length & $234 \mathrm{~mm}$ \\
\hline
\end{tabular}

III. RESULT AND DISCUSSION

In this section, the results of dual fuel operation of Biogas-Diesel is compared with neat diesel are presented.

\section{HC Emission (Unburnt hydrocarbons)}

Unburnt hydrocarbon emissions are the direct result of incomplete combustion. The term hydrocarbon means organic compounds via gaseous state. Solid hydrocarbons are the particulate matter. Figure-4 shows the variation of hydrocarbon emission against brake power. The hydrocarbon emission is high in dual fuel mode compared to neat fuel mode in the entire power range. The difference in $\mathrm{HC}$ emission is high in low power ranges and narrow in high power ranges. Incomplete combustion of Biogas due to insufficient ignition sources in the low power range is the reason for high hydrocarbon emission.

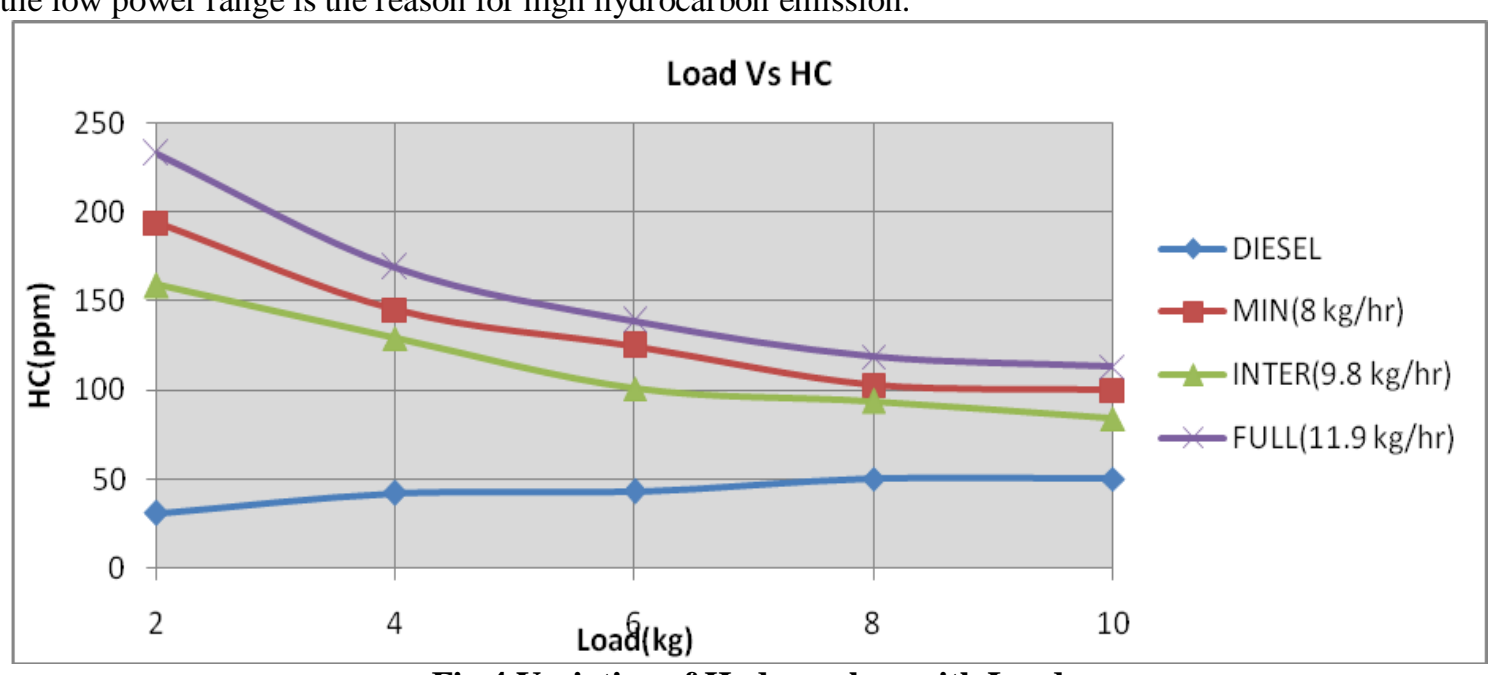

Fig.4 Variation of Hydrocarbon with Load

The HC emission in the dual fuel mode of biogas-diesel is $233 \mathrm{ppm}$ at low load condition and which decrease with increase in load on the engine which is $113 \mathrm{ppm}$ at higher load condition. At low loads, the inducted Biogas air mixture is too lean and this causes the flame to quench near the combustion chamber walls which leads to high $\mathrm{HC}$ emission. As the load increases, the $\mathrm{HC}$ level reduces. This is because combustion is complete due to high gas temperature in the cylinder.

\section{CO Emission}

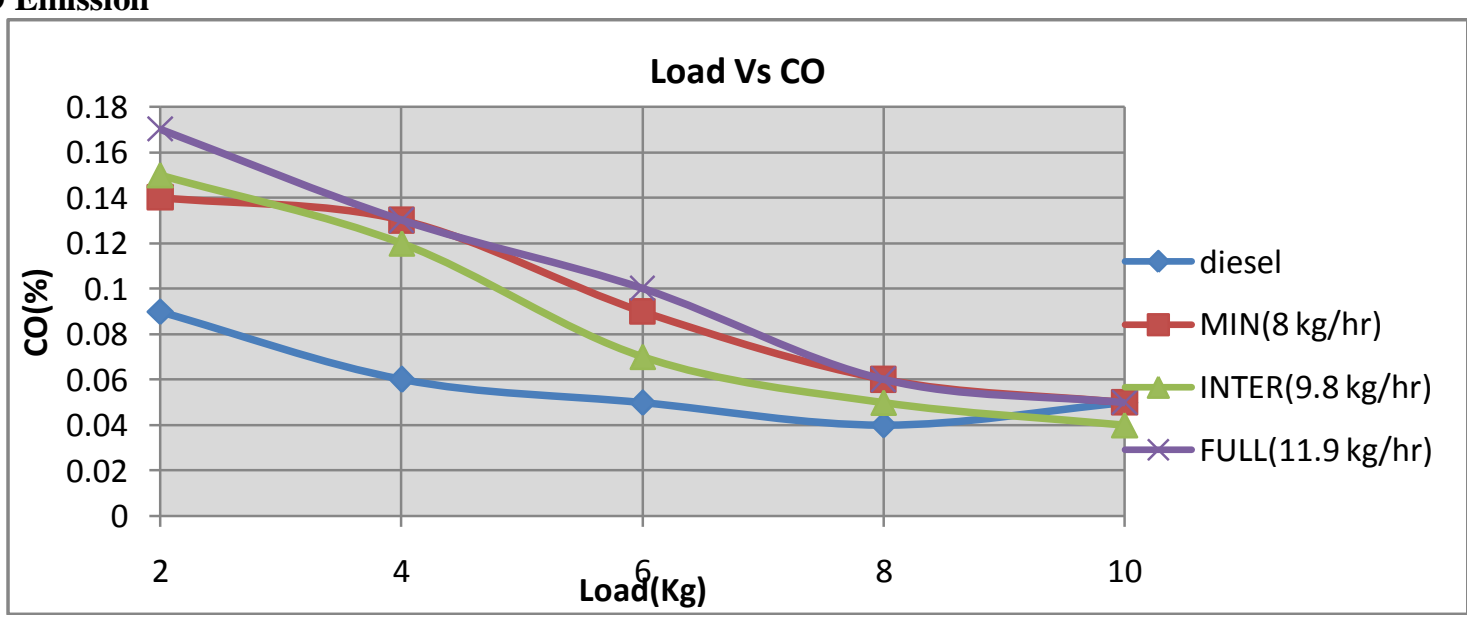

Fig.5 Variation of CO with Load 
Carbon monoxide is a product of incomplete combustion due to insufficient amount of air in the airfuel mixture or insufficient time in the cycle for completion of combustion. $\mathrm{CO}$ emission is toxic and must be controlled. Generally CI engines operate with lean mixtures and hence $\mathrm{CO}$ emission will be low. The variation of $\mathrm{CO}$ emissions with load is shown in Figure-5. The $\mathrm{CO}$ emission is increased throughout the engine operation in dual fuel mode compared to neat fuel mode. $\mathrm{CO}$ emission greatly depends on the air fuel ratio. The Biogas was inducted through the inlet manifold; the oxygen availability in the intake mixture was less, which results in higher emission. The $\mathrm{CO}$ emission is $0.17 \%$ at low load condition and $0.05 \%$ at higher load condition. As increased in load the difference of $\mathrm{CO}$ emission is decreased and which almost same as neat fuel value.

\section{NOx Emission}

Oxides of nitrogen (NOx) that occur in the engine exhaust are the combination of nitric Oxide (NO) and nitrogen dioxide (NO2). Nitrogen and oxygen react at relatively high temperatures. Therefore high temperature and availability of oxygen are the two main reasons for the formation of NOx. The variation of NOx emission with brake Load is shown in Figure-6. NOx level is reduced in dual fuel from $27 \%$ to $57 \%$ from lower load to higher load condition than the neat fuel operation.

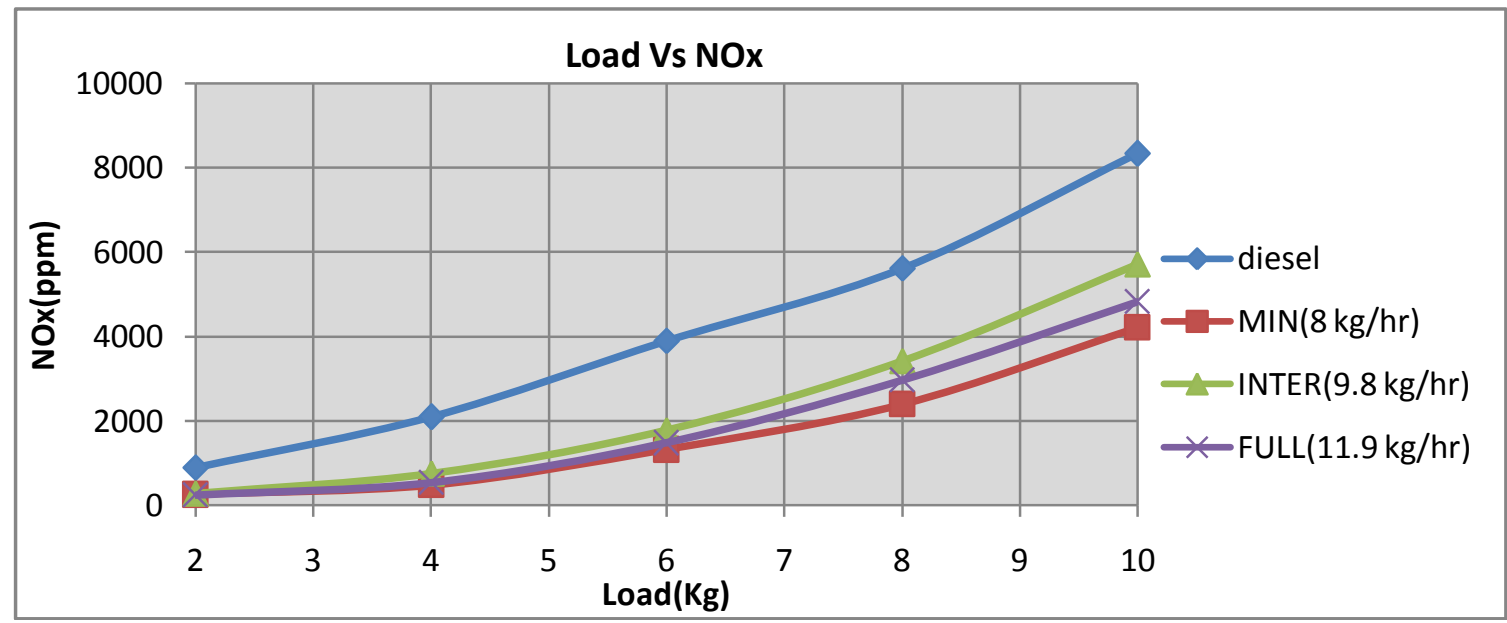

Fig.6 Variation of NOx with Load

\section{Oxygen (O2) concentration}

At low speed the oxygen concentration is very high in the exhaust gas and decreases rapidly with the increase of speed. Reason for the reduction is due to the complete combustion effect with increasing speed engine. O2 concentration in the biogas-diesel emission was higher than that of diesel throughout the speed range, and on the average, it was $19 \%$ and $17 \%$ at the lower load and higher load condition respectively. Where neat fuel operation have $18 \%$ and $16 \%$ at lower load and higher load condition. Figure-7 Shows the variation of $\mathrm{O} 2$ with respect to load.

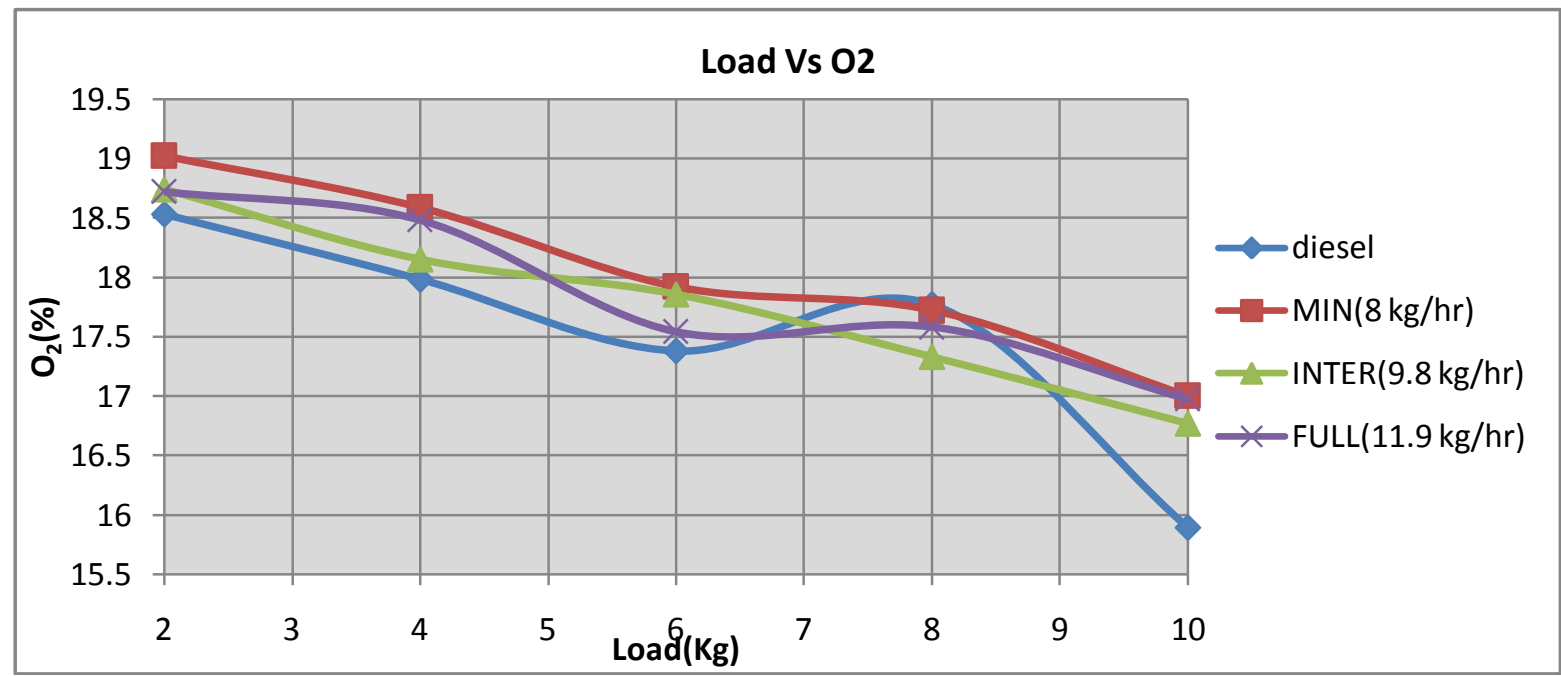

Fig.7 Variation of $\mathrm{CO}_{2}$ with Load 


\section{Carbon dioxide (CO2) emission}

Figure shows the variation of $\mathrm{CO} 2$ emission with respect to load. The $\mathrm{CO} 2$ emission was almost same almost $1 \%$ at the lower load condition. With increase in load the $\mathrm{CO} 2$ emission is decreased to $0.8 \%$ than the neat fuel operation. Dual fuel have $1.1 \%$ \& $2.36 \%$ and neat fuel have $1.14 \% \& 3.1 \% \mathrm{CO} 2$ emission respectively at lower and higher load condition.

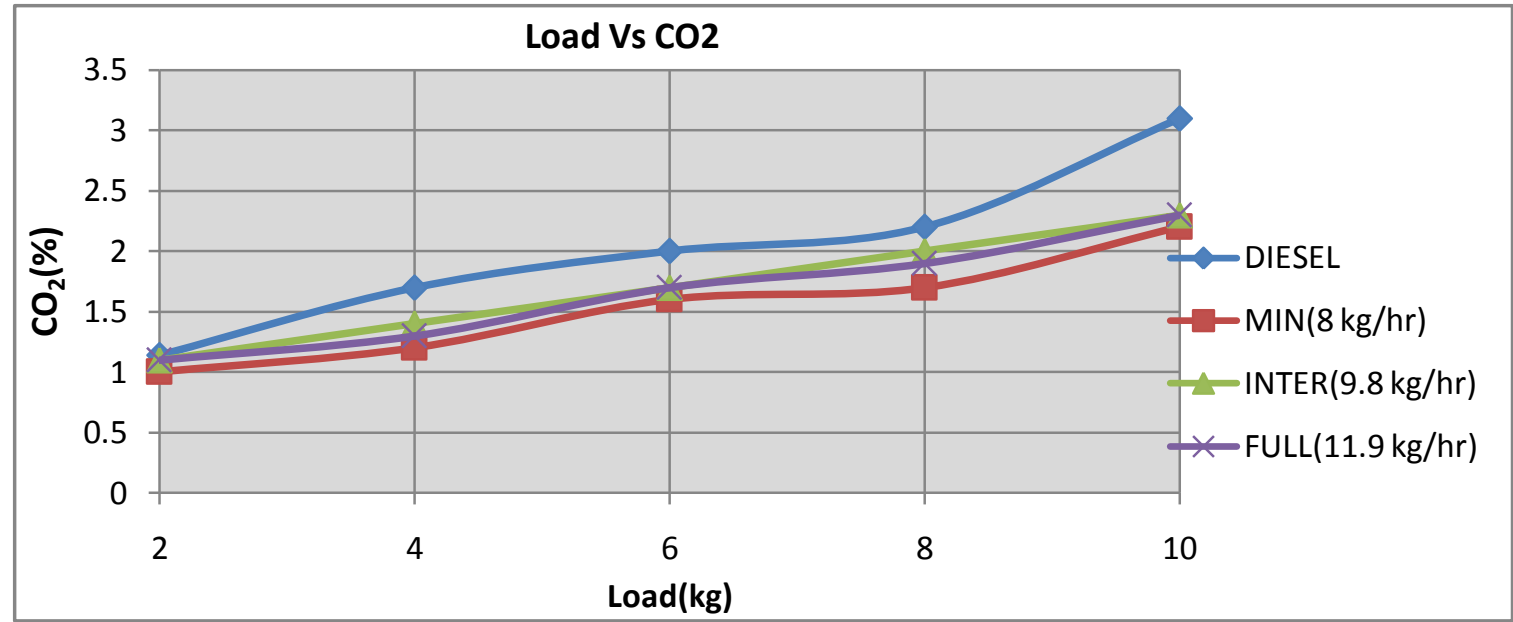

Fig.8 Variation of $\mathrm{CO}_{2}$ with Load

IV.

CONCLUSION

The following conclusions are drawn based on the experimental investigation.

(a) The emission of NOx and $\mathrm{CO}_{2}$ dual fuel have lower than the neat fuel operation. The NOx is reduced $27 \%$ to $57 \%$ and $\mathrm{CO} 2$ emission is reduced from $4 \%$ to $18 \%$ from lower load to higher load condition.

(b) The emission of HC, CO and O2, dual fuel has higher than the neat fuel operation. The HC emission is 200 $\mathrm{ppm}$ at lower load and this reduced to $63 \mathrm{ppm}$ at higher load than the neat fuel. CO emission at $0.17 \%$ at low load and this reduced to $0.05 \%$ which almost same value as neat fuel. And $\mathrm{O} 2$ emission is $0.19 \%$ higher than the neat fuel operation and this difference is increased with load and the $\mathrm{O} 2$ emission is increased to $1.08 \%$.

\section{REFERENCES}

[1] N.H.S.Ray, M.K.Mohanty and R.C.Mohanty, "Biogas as Alternate Fuel in Diesel Engines: A Literature Review" IOSR Journal of Mechanical and Civil Engineering (IOSR-JMCE) (Sep. - Oct. 2013).

[2] Debabrata Barik, S. Murugan," Production and Application of Biogas as a Gaseous Fuel for Internal Combustion Engines" International Journal of Engineering Research \& Technology (IJERT) Vol. 1 Issue 7, September - 2012 ISSN: 2278-0181

[3] Phan Minh Duc and Kanit Wattanavichien, "Study on biogas premixed charge diesel dual fuelled engine "Energy Conversion and Management 48 (2007) 2286-2308.

[4] N. Tippayawong, a. Promwungkwa and p. Rerkkriangkrai," Durability of a small agricultural engine on Biogas/diesel dual fuel operation" iranian journal of science \& technology, transaction b: engineering, vol. 34, no. B2, pp 167-177 Printed in the islamic republic of iran, 2010 () shiraz university

[5] R. Chandra a, V.K. Vijay b, P.M.V. Subbarao cand T.K. Khura a," Performance evaluation of a constant speed IC engine on CNG, methane enriched Biogas and biogas" Applied Energy 88 (2011) 3969-3977, journal homepage: www.elsevier.com/locatelapenergy.

[6] Kamil Ahmed, Balewgize Amare and Dr. A.Venkata Ramayya," Experimental Investigation on Thermal Efficiency of Diesel Engine with Jatropha-Diesel Blend with Biogas", International Journal of Engineering Research \& Technology (IJERT) Vol. 2 Issue 7, July - 2013, IJERTIJERT, ISSN: 2278-0181

[7] N. Tippayawong, ** a. Promwungkwa and p. Rerkkriangkrai," durability of a small agricultural engine on biogas/diesel dual fuel operation*"iranian journal of science \& technology, transaction $b$ : engineering, vol. 34, no. B2, pp 167-177Printed in the islamic republic of iran, 2010, (C) shiraz university

[8] JIANG Yao-hua, XIONG Shu-sheng, SHI Wei, HE Wen-hua, ZHANG Tian and LIN Xian-ke" Research of Biogas as Fuel for Internal Combustion Engine", Research of Biogas as Fuel for Internal Combustion Engine " Amit Jhalani - Academia.edu

[9] Prof. Sharad P. Bargat, Prof. Pravin S. Wagh and Prof. Uday A. Kakde," Application of Wood Chip Producer Gas and Bio-diesel Blends In CI Engine", International Journal of Engineering Research \& Technology (IJERT) Vol. 1 Issue 3, May - 2012 